ELORE (ISSN 1456-3010), vol. $12-2 / 2005$.

Julkaisija: Suomen Kansantietouden Tutkijain Seura ry. Taitto: Jukka Talve ja Outi Fingerroos. [http://cc.joensuu.fi/ loristi/2_05/asp2_05.pdf]

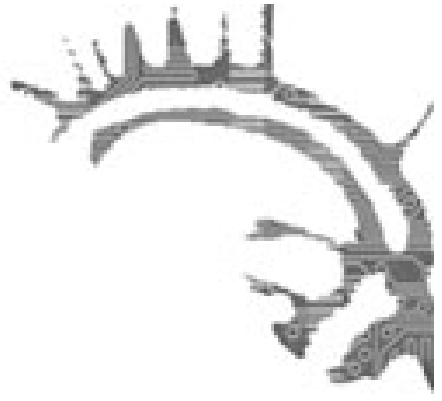

\title{
Legends of Trolls AND THE Bible
}

\author{
Camilla Asplund Ingemark
}

This article aims to see how legends about trolls have been moulded by their relationship to the larger folk tradition, and to other traditions, primarily the religious one. The primary material used for this purpose consists of 123 records explicitly dealing with trolls or linguistic equivalents thereof (Finland-Swedish records tend to be fewer in number than a corresponding Finnish material would be). It has been collected by many different fieldworkers, in various parts of the Swedish-speaking districts in Finland, from the 1850s to 1925. In addition to these, I have utilised a secondary material of records pertaining to other, related aspects of folklore and folk belief, amounting to 72 texts in total. A major share of the material stems from the Rancken collection (R), presently deposited at the Department of Folklore at Åbo Akademi University, and the Folk Culture Archives of the Swedish Literature Society in Finland (SLS); the remainder is drawn from printed sources. Obviously, I cannot cite the entire material within the confines of this article - I will have to content myself with giving some examples - but it constitutes the basis for my interpretation of individual texts.

The Rancken collection is the result of the earliest, reasonably organised attempt at preserving Swedish-language folklore in Finland. J. O. I. Rancken (1824-1895) believed in the importance of the Swedish tradition in Finland, as it formed a bridge between Finnish tradition and traditions in Sweden (Wolf-Knuts 1997, 33), and he made his pupils write essay assignments on the traditions current in their home district. The collecting activities of the Swedish Literature Society were initiated in a more politically charged atmosphere than Rancken's; the society was founded in 1885, when the conflict between the Swedish and the Finnish language parties had been going on for some time. The express purpose of the society was to promote and legitimise the existence of a Swedish culture in Finland (Steinby 1985, 14-18), and to demonstrate its importance for the nation as a whole. Previously, Finnish national culture had been envisioned solely in terms of Finnish culture and folklore, also among Swedish-speakers (see Andersson 1967, 120; Anttonen 2003; Honko 1980; Wolf-Knuts 1997, 33), and that is why the collection of Swedish folklore in Finland was rather slow to catch up with the 


\section{Camilla Asplund Ingemark}

Finnish. In the beginning, fieldwork was conducted by scholarship holders, often students and elementary school teachers. In 1908, however, collection was entrusted to "competent professionals", which usually meant academics (Bergman 1981, 22-23).

The existence of intertextual connections between legends and religious texts in this period naturally requires a historical and social context in which narrators could become personally familiar with religious teachings, and such is indeed the case. The $19^{\text {th }}$ and early $20^{\text {th }}$ centuries were the heyday of the revivalist movements: the Pietists and the Evangelicals were the most prominent in the Swedish-speaking areas, drawing great crowds to their church services (both remained within the Lutheran church). Several of these movements stressed the importance of individual devotion, and in the early $19^{\text {th }}$ century, the Bible began to be circulated in cheap editions, making the Bible of Charles XII, originally sanctioned in 1703, the first Bible intended for individual reading (Dahlbacka 1987; Olsson 2001, 62-65; Pleijel 1967, 37-39). The message of the Bible was also spread in other ways: the Gospels and Epistles were read in mass, and Martin Luther's catechism was compulsory reading for parishioners if they were to pass the examinations at catechetical meetings (Näsman 1979, 45; Pleijel 1967, 13, 44). Confirmation classes and Sunday schools also contributed to the religious education of the parishioners (Näsman 1979, 46, 75-76). Moreover, with the repeal of the prohibition against private religious meetings from 1726 in the new Church Law of 1870 , both the clergy and laymen launched into a flurry of activity, organising Bible classes and edifying meetings in the villages (Åkerblom 1963, 158). Thus, people had ample opportunity to familiarise themselves with the religious tradition.

\section{Constructing an InTERTEXTUAL Network}

The investigation of the troll narratives' relation to the larger domain of folk tradition and to religious tradition has been carried out to uncover their place in the narrators' networks of association, and the cultural system of referentiality to which they belonged (for the latter term, see Stark-Arola 1998, 188). This research agenda rests on the notion of intertextuality, proposed by Julia Kristeva in 1969, which is characterised by the construal of all text as a mosaic of quotations, the absorption and transformation of other texts. These other texts constitute the intertexts of the text studied (Kristeva 1978, 84-85).

From a folkloristic perspective, the merit of the concept lies in its reformulation of the relation between text and context, that ever-popular object of debate, by subordinating both to the broader sphere of intertextuality which can, in some senses, be equated with tradition, and in others not. In Kristeva's original model, the author was the focus of interest, and the text s/he produced was the result of the reading and rewriting of context, understood as a contemporary or anterior literary corpus, which was also the receiver to which s/ he addressed the text (Kristeva 1978, 83-84). In later reworkings, the emphasis has 


\section{LEGENDS OF TROLLS AND THE BiBLE}

fallen somewhat differently. Roland Barthes chose to dispense with the author altogether, elevating the text and "the innumerable centres of culture" from which it sprang to prime position (Barthes 1977, 146); Michael Riffaterre preferred to give precedence to the new entity created by the combination of the sign systems of two discrete texts - the text studied and the intertext necessary for comprehending it - as it accounted for the uniqueness and one, unitary significance of the text (Riffaterre 1990, 61, 57-58; Riffaterre 1978, 2-6, 13, 19). Many folklorists have given pride of place to the intertextual whole formed by the recurrence in different texts of structural elements, themes and phrases, variously labelled the intertextual/epic universe (Tarkka 1993, 173; Tarkka 1994, 251), pool of tradition (Honko 1998, 69) or ethnopoetic/ethnocultural substrate (Harvilahti 2000, 68; Harvilahti 2003, 125; cf. Harvilahti 2001), for example. Networks of association is my own rendition of this concept. This realm of intertextuality is basically the realm of tradition - to which John Miles Foley's related notion of traditional referentiality (Foley 1991) testifies - but it is perhaps less monolithic, and it is not limited to folk tradition alone; all traditions of a given culture could potentially belong to it. Thus, the concept can be employed to situate folk tradition, or aspects of it, within the broader framework of a culture, and in folkloristic research, this has often meant relating folklore to religious conceptions (Stark 2002; Wolf-Knuts 2000; Asplund Ingemark 2004).

In order to study the process in which narratives of trolls were linked to the larger intertextual sphere, I have applied Lotte Tarkka's concepts of metaphor and metonymy, and of the creation of a series of metaphors, since I believe they could be of assistance in locating the central themes of a narrative as well as in the articulation of the relationships between narratives. In Tarkka's explication of the concepts, metaphor is taken to refer to the differences and similarities between a pair of opposites belonging to separate conceptual spheres - for example the human village and the supernatural forest - and these poles are then bridged by metonymy, which combines elements of the same conceptual order into a sequence, through ritual or other forms of communication, for instance. In my own utilisation of metonymy, I have regarded it as the point of transition from one pole of the metaphor to another, a usage that is related to Tarkka's, but maybe not what she really had in mind. A series of metaphors is generated when different texts use the same themes and epithets, making individual metaphors comparable with, but not identical to other metaphors of the series (Tarkka 1994, 293-294).

In verbally describing these relationships, I have employed three designations: agreement with the intertext; inversion/reversal of the intertext (used synonymously), and negation of the intertext (cf. Wolf-Knuts 2000 for a rather similar division). I could have added disagreement with the intertext, but I do not consider it of sufficient analytical value in this case to deserve inclusion; mere difference is not informative enough.

The primary material for this part of the study has been furnished by two groups of texts dealing with a troll's abduction of a young woman, her subsequent liberation from the troll by a parson pronouncing the benediction, and the 


\section{Camilla Asplund Ingemark}

banishment of the troll from its habitation. Some variants contain only the story of the girl's abduction and her rescue, others comprise both the account of the girl's abduction and the banishment of the troll, and yet others concentrate exclusively on the exorcism of the troll. All narratives, eight in total, have been collected in the Ostrobothnian parish of Vörå (Finnish: Vöyri), or in the neighbouring parishes - the closest I could come to a thick corpus (Honko 2000, 15-17) - and they seem to reflect a vigorous, or at least well-documented, local tradition. Many collectors active in the parish in this period recorded one or more variants of the story.

In addition to these texts, I have examined a vast amount of texts recorded in the parish and nearby $(10,000$ records is a rough estimate) and selected those I thought might be relevant for the construction of the intertextual network in which the narratives were incorporated. I have looked for recurrent structures, themes and phrases, and tried to identify clusters of themes engendered by their inclusion in a common series of metaphors. An extensive intertextual network has emerged, featuring such diverse topics as blindness and illumination (figurative and literal), sin and redemption, vanity and shame, hypocrisy and holiness. The texts examined below, however, relate to the themes of hypocrisy and holiness (for a fuller analysis, see Asplund Ingemark 2004; cf. Asplund 2001).

\section{The Failings of an Exorcist}

There are many narratives of brownies and trolls. I have heard many old tales about such [things]. Once it was told that a girl was abducted by the trolls. On Sundays they let her go to church, but required that she should leave church before the parson had pronounced "Lord bless us". She did this, but one Sunday she stayed. Then the enchantment was broken and she got free. Before, she thought she was dressed as finely as a princess, but suddenly she was so badly dressed. Now when the parson got to know this, he made the girl follow him to the dwelling of the trolls. He commanded the trolls to leave the place, but then they started crying, and asked if they could lock the door and take the keys with them. Then it is told that they flew away as two black birds. (SLS 338, 21-22.)

This text, contained in an essay by Elna Källbacka and submitted to the Swedish Literature Society in Finland in 1922, is a fairly standard variant of the story, comprising both the element of abduction and rescue, and of banishment. As in the other texts I studied, the site of the girl's liberation from the trolls is the parish church, and the affluence of the otherworld, here symbolised by her fine clothes, is stressed. In this respect, Källbacka's narrative agrees with other variants of the legend. However, there is one feature of this text that is quite unusual in similar narratives from the parish of Vörå, and that is the immediate success of the parson in expelling the trolls; most priests have to make repeated attempts before they finally manage to perform their (usually self-set) task, and we might wonder why 


\section{LEGENDS OF TROLLS AND THE BiBLE}

this parson is successful, but not the others. We can start with what the stories themselves mention as reasons for the parsons' failure. The following text was submitted by J. Kaustinen, a local collector in the parish of Vörå, to the journal Hembygden:

Much discussed is the Troll Hill with its cave, the so-called "troll cottage". This cave is also quite remarkable, so that it is not strange that folk belief has made it a haunt of trolls. The trolls living there have terribly alarmed the people all around and even stolen silver objects from the churches, wherefore the parson finally had decided to "chant them away" [i.e., banish them]. The first time he was there to read the trolls did not care in the least about it, as he had no coat. The second time they did not care about his lesson either, as he had pulled on the left shoe before the right. The third time all must have been as it should, for then the trolls had to go. Before they left, they asked to be allowed to close the door to their room, which was granted. Therefore you cannot get further in than into their hall. Then they flew screaming away in the form of three ravens. After that no-one has ever seen them. (Hembygden 1912, 20-21.)

The first time, the parson has neglected to don one of the signs of his office, his coat, and his spiritual authority suffers accordingly. The second time, he has forgotten to put on his shoes in the correct order, and thereby diminished his own ritual authority once more. Why he made these mistakes at all is not explained, but a number of possibilities present themselves. It may be a question of possessing the right kind of knowledge; some clergymen have it, and some do not (cf. WolfKnuts 1991, 184). From this point of view, knowledge is most definitely power. It could be a matter of over-confidence in his own superiority, a rather plausible interpretation given the aversion against lords - the clergy, school teachers, members of the parish and municipal councils - attested in Vörå (Wolf-Knuts 1991, 132; Wolf-Knuts 1992, 113). A third possibility is hinted at by a Biblical intertext, the story of the disciples' failure to banish a deaf and dumb spirit from a young man. Unsure of why they had not succeeded, they asked Jesus about it:

Then came the disciples to Jesus apart, and said, Why could not we cast bim out? And Jesus said unto them, Because of your unbelief: for verily, I say unto you; If ye have faith as a grain of mustard seed, ye shall say unto this mountain, Remove hence to yonder place; and it shall remove; and nothing shall be impossible unto you. Howbeit this kind goeth not out but by prayer and fasting. (Matthew 17, 19-21.)

Jesus does emphasise the importance of appropriate ritual preparation, in this instance prayer and fasting, but he also points to a graver flaw: the disciples' lack of faith. I argue that there is an intertextual relation between the legends of trolls and this Biblical text - in other words, that they form a series of metaphors - and this judgement is based on the similarities in structure and theme of all three 


\section{Camilla Asplund Ingemark}

stories. All of them depict a similar situation, the banishment of troublesome supernatural creatures by a figure of religious authority (a parson or Christ), and they ponder the conditions for the success of this enterprise. A representation of the structure of the stories, identifying the poles of the metaphor (the first and third column) and the metonymy effecting the transition between them (the second column), might look like this:

SLS 338, 21-22:

Parson attempts to banish trolls - Ritual purity - Success

Hembygden 1912, 20-21:

Parson attempts to banish trolls - Ritual impurity - Failure -

Parson attempts to banish trolls - Ritual purity - Success

Matthew 17,19-21:

Disciples attempt to banish spirit - Ritual impurity and unbelief - Failure Christ attempts to banish spirit - Ritual purity and belief-Success

I find it quite conceivable that the narrators of the legends had this Biblical narrative, or some other story of Christ's banishments of evil spirits, in the back of their minds when they constructed their own texts, for the simple reason that Christ would furnish the obvious model for the narrative construction of an exorcist in a Christian culture. Several of his miracles are exorcisms (see e.g. Matthew 15, 22-28; Mark 1, 23-26; Mark 5, 2-13; Mark 7, 25-30; Luke 4, 33-35; Luke 8, 26-33; Luke 9, 38-42), and it is likely that people were familiar with at least some of the stories on this theme. The overtly religious setting of the troll legends, involving a Christian minister, also contributes to the comparability of the folk legends and the Biblical narratives.

I believe that the intertextual link between the New Testament text and the legends about trolls enabled the narrators to voice their opinions about clergymen without actually doing so openly. For it is quite striking that of all the things clergymen are accused of in folk tradition - trickery, greed, fornication and adultery, theft, uncouth manners and stupidity (see Finlands 1920, 207-210, 236-277; cf. Apo 1989, 204-205) - lack of piety is not one of them, as far as I know. Whether this is because it was too sensitive a topic in the age of the revivalist movements, when personal devotion played such a prominent role in religious life, or whether collectors did not gain access to this kind of anticlerical folklore, or it really did not exist, remains obscure. Nevertheless, if the audience hearing the troll legends connected them with the Biblical narratives of Christ's banishments of evil spirits and disease demons, this one, or Mark 9, 14-29, would be the closest counterpart, since this is the only story in which Jesus dwells on the reasons for other people's failure to repeat his miracles. Thus, having made the connection to the Biblical story, the listeners might have recalled this explanation, and then they also knew why the parson failed so miserably. Notwithstanding, the parson is victorious 


\section{LEGENDS OF TROLLS AND THE BiBLE}

eventually, and just as the disciples did - St. Peter cured the sick Aeneas of Lydda and resuscitated the dead Tabita in Joppe (Acts 9, 32-42) - he has retrieved his mustard seed of faith. Hence the minister in Källbacka's text is more akin to Jesus in St. Matthew's story, as he performs the banishment without effort and demeaning defeat, while the parson in Kaustinen's record is more similar to the disciples who failed initially, but returned with a vengeance.

In both Källbacka's and Kaustinen's records, the trolls make a request to their exorcist, to be allowed to seal off their abode when they are forced to leave it. The theme of a petition directed at the exorcist is present in another account of Christ's miracles, namely the story of the Gadarene Swine:

AND they came over unto the other side of the sea, into the country of the Gadarenes. And when he was come out of the ship, immediately there met him out of the tombs a man with an unclean spirit, Who had his dwelling among the tombs; and no man could bind him, no, not with chains: Because that he had been often bound with fetters and chains, and the chains had been plucked asunder by him, and the fetters broken into pieces: neither could any man tame him: And always, night and day, be was in the mountains, and in the tombs, crying, and cutting himself with stones. But when he saw Jesus afar off, he ran and worshipped him, And cried with a loud voice, and said, What have I to do with thee, Jesus, thou Son of the most high God? I adjure thee by God, that thou torment me not. For he said unto him, Come out of the man, thou unclean spirit. And he asked him, What is thy name? And he answered, saying, My name is Legion, for we are many. And be besought him much that he would not send them away out of the country. Now there was there high unto the mountains a great herd of swine feeding. And all the devils besought him, saying, Send us into the swine, that we may enter into them. And forthwith Jesus gave them leave, and the unclean spirits went out, and entered into the swine: and the herd ran violently down a steep place into the sea, (they were about two thousand;) and were choked in the sea. (Mark $5,1-13$.

In the Biblical narrative the unclean spirits want compensation for losing their host, and Christ is willing to grant their request (to the detriment of the owner of the swine). The trolls in Källbacka's and Kaustinen's texts have a more modest proposal, as they only wish to be able to close the door behind them and bring the keys with them at their departure, and the parson sees no reason to deny them that right. There are instances, however, when the trolls do not get their way, and this is usually due to the nature of their request. The parson in the following record, made by V. E. V. Wessman in 1917, was not amused by their wish:

In Koskeby there is a hill, which is called the Troll Hill. Once a girl went to collect the cows, and then the troll took her. One Sunday she asked to be allowed to go to church, and was given leave, but she would not be allowed to stay until the parson pronounced the benediction. She came to the church, and was so finely dressed that 


\title{
Camilla Asplund Ingemark
}

all the people looked at her. She did not obey the troll in the end but was there when the parson pronounced the benediction, and then those fine clothes turned into such as they had been while she was herding the cows.

Later on two Thursday mornings a parson was to banish the trolls. The first morning the parson had put on the left boot first, and for this the trolls chided (reproached, censured) bim. The second morning there was also something wrong with him, but the third morning they left and were like black ravens. They had asked if they could not go to some other hill, but the parson said that they could not be allowed to stay in the whole kingdom. - In the same bill there is a well, which is called the Troll Well. (SLS 280, 635-636.)

The parson refuses to allow the trolls to move to another hill, or even stay in the kingdom, quite in contrast to the compliance of Christ in a similar situation. His sense of responsibility to his neighbours and fellow countrymen deters him from accepting this simple solution, and Wessman's text is a negation of the other legends and the Biblical story in this regard. The parson's behaviour might be modelled on another image of Christ, the Jesus of incantations and of the bistoriolas incorporated into them. These can include Biblical characters, and in this context, Jesus is not as forgiving as in the Gospel text:

\author{
Christ was to walk over the lake \\ Then he met kväison by the shore. \\ Where are you going? Christ asked. \\ I shall go onto land \\ And rot flesh and bone. \\ Christ said: \\ I deny you that. \\ (SLS 215, 44.)
}

Here Christ exploits his divine authority to stop the disease demon from causing the illness called kväison, which attacked the udders of the cows and was characterised by swellings. Hence this text, recorded by Jacob Tegengren in 1912 or 1913, is also a negation of the Gospel and the legends in which the parson grants the trolls' request, and it is in agreement with Wessman's record. Obviously, Wessman's and Tegengren's texts deal with a much more serious situation, while Källbacka's and Kaustinen's concern a somewhat frivolous one in comparison. These texts also form a series of metaphors in which the granting or denial of the supranormal beings' request is the common theme:

SLS 338, 21-22:

Trolls make request-Parson is merciful - Request granted 
Hembygden 1912, 20-21:

Trolls make request - Parson is merciful - Request granted

Mark 5, 1-13:

Spirits make request - Christ is merciful - Request granted

SLS 280, 635-636:

Trolls make request - Parson is merciless - Request denied

SLS 215, 44:

Disease demon reveals evil plans - Christ is merciless - Realisation of

plan denied

Viewed in this light, there are distinct similarities between the narratives, both in terms of structure and theme. I have argued that this state of affairs could be interpreted as an indication that the legends and the Biblical texts were part of the same system of referentiality, and that they were included in a larger repertoire of cultural images and symbols available to narrators in the parish of Vörå in this period (cf. Stark-Arola 1998, 188). Furthermore, this has consequences for our interpretation of folk belief narratives in particular, and folklore in general. It is no longer possible to approach folklore without considering potential connections with the religious tradition.

\section{INTERDISCURSIVITY AND Power}

Nevertheless, despite the similarities between folklore and religious texts, there are still substantial differences, not least in the realm of power. I believe that the parishioners of Vörå used the narratives discussed here to contest or support the social power of the clergy, either by exposing their inadequacy or by extolling their virtues; my material provides scope for both perspectives. In this respect, the relationship between folklore and the Bible is interdiscursive in nature as well, since they represent different discourses, defined as specific ways of constructing a subject matter or area of knowledge according to certain principles (Fairclough 1992, 128; Foucault 1999, 106). Discourses are linked to power, as they are the site and object of the continual construction and contestation of power relations; this means that they are important instruments in maintaining existing power relations, but also in overthrowing them (Mills 2002, 42).

Michel Foucault has described the relation between power and resistance as one of mutual dependence: one cannot exist without the other (Foucault 2002, 125-127). For the individual, it implies that subjectivity is both an effect and a vehicle of power, and that $\mathrm{s} / \mathrm{he}$ is subjected to as well as exercises power (Foucault 1980, 98). The narratives about trolls investigated here illustrate this rather well. It was difficult for the narrators to break free from the religious tradition 


\section{Camilla Asplund Ingemark}

- and rather pointless in these specific examples, dealing as they do with an overtly religious theme - so their resistance was mounted in other ways. They ridiculed incompetent representatives of the church, and they blatantly failed to use any of the words and phrases derived from the Bible, which had a characteristic, archaising idiom in the Bible of the Charles XII (Olsson 2001, 58-59, 40).

The folkloric and the religious discourse did of course belong to a broader interdiscursive network, and I have tried to identify some of the other discourses influencing their relationship. The religious discourse was socially dominant and more esteemed as a valorised form of knowledge, but the folkloric discourse was being reappraised in this period. The newly founded discipline of folkloristics raised the status of the folkloric discourse, which turned into a partially valid form of knowledge, but only at the expense of being exoticised by researchers who no longer took part in it themselves (cf. Burke 1983, 302-318). They wanted to keep the folkloric discourse pure from adulteration by the religious discourse, since folklore contained the remains of an ancient, heathen culture (see e.g. Hembygden 1910, 149; Nyland 1887, vii-viii; Thurman 1891, 104-105).

The discourse of popular enlightenment, as manifested in the history books of the period, articulated the relation between folklore and religion in another way. In the absence of a highly developed prehistorical archaeology, folklore was employed to cast light on Finland's ancient past, producing a kind of folklorised history. Yet this history was often thought to be guided by the hand of God (Hallstén 1852, 3-4; Schybergson 1895, v), which reinforced the dominance of the religious discourse.

Finally, the discourse of liberalism, which advocated the liberation of the individual from the tutelage of the church, tended to undermine the authority of the religious discourse. The discourse of liberalism itself did not become part of the folkloric discourse - it was chiefly popular in bourgeois circles (Näsman 1979, 82-84) - but it had initiated the discursive detachment of the individual from the church.

In the case of the other clusters of themes mentioned above, the narrators exploited the intertextual and interdiscursive connections to the religious discourse in order to challenge certain Christian doctrines, such as the possibility of a return to Paradise only in the afterlife, by producing their own version of a Paradise on earth, the world of the troll. This supernatural realm, free from the arduousness of hard physical labour, free from care, and (here is the but) free from the blessings of Christianity, might have been constructed to eliminate a perceived lack in the official doctrine. At the same time, it is evident that the pagan status of this otherworld was viewed as a problem, and it remains a wonderful, but slightly marred dream: it is not the proper place for humans.

Mikhail Bakhtin's distinction between authoritative discourse and internally persuasive discourse can be used to shed light on this multifaceted relationship between the folkloric and the religious discourse. In his explication of the concepts, the religious discourse is a typical example of an authoritative discourse: it demands acknowledgement quite regardless of whether it is capable of persuasion or not, 


\section{LEGENDS OF TROLLS AND THE BiBLE}

and it belongs to a valorised past (the time of the patriarchs, the lifetime of Christ) and elevated contexts (mass). It is impervious to external influence and stays essentially unchanged (Bakhtin 1986, 342-344). Internally persuasive discourse is its opposite; it is open to the influence of other discourses, with which it must compete to gain credence and acceptance. It can be placed in new contexts to yield new meanings, and it is firmly rooted in the present (Bakhtin 1986, 345-346).

Bakhtin's characterisation of the two types of discourses is somewhat exaggerated, but the distinction is nevertheless useful. When the narrators of the troll narratives approached the religious discourse, they did not turn to an authoritative discourse; they transformed it into an internally persuasive discourse, which could be examined, accepted or contested. They recontextualised the religious discourse within the frame of the folkloric discourse, transposing elements of the former into the latter, and simultaneously exposed the weaknesses of the religious discourse and pin-pointed its boundaries (cf. Bakhtin 1986, 343, 347-348). For instance, the transference of the Biblical discourse of exorcism to the banishment of trolls serves to highlight the precariousness of such a discourse in the mouths of the unworthy, something I have interpreted as a testing of the limitations of the religious discourse.

As we have seen, however, intertextual connections are not only used to challenge the religious discourse, but also to affirm it. The assertions of the religious discourse have been evaluated in the light of other discourses, and they have been found to be persuasive, leading the narrators to adopt them as their own. In the first example given above, the piety of the parson, and therefore his high social status, is defended; in other cases, the values endorsed are social as well as Christian, making them doubly significant.

Thus, the power of the religious discourse is not absolute; it is constantly in dispute. Notwithstanding, in the period studied, it did have some weapons at its disposal that were difficult to disregard. This brings us to what Michel Foucault has called the micro-mechanisms or techniques of power, i.e., the workings of power in everyday life (Foucault 1980, 101). The aim of the church was to constitute individuals as Christian subjects, and the techniques of power utilised consisted of forms of examination, for example. Catechetical meetings, confirmation classes and Sunday schools provided the opportunity for these examinations, and parishioners were hardly unaware of this fact. Many recorded jocular tales revolve around intentionally or unintentionally stupid and degrading responses to questions posed at catechetical meetings, a very serious occasion in real life, and the stories imply a resistance to the efforts of the clergy to properly Christianise their parishioners (see Finlands 1920, 271-274). A condition for these forms of examination was the discipline of the body achieved in the act of reading, as examination required successful individual study of religious texts, mainly the catechism of Martin Luther. It gave the body power and knowledge, but it was also a method of Christianisation. 


\section{Camilla Asplund Ingemark}

\section{ConClusion}

As I hope to have shown, the relationship between legends of trolls and religious texts is a many-sided and important one. It gives us pause, as folklorists, to reconsider the interpretative framework we bring to bear on the folklore of the $19^{\text {th }}$ and early $20^{\text {th }}$ centuries, and it invites us to trace similarities - and differences - even where they are none too apparent. The banishment of trolls does of course have clear links to religion, but in other cases the connection may be less evident. Sometimes only the recognition of a theme or a storyline reveals the presence of an intertextual relation.

I think that folk belief as we have come to know it - both in terms of structure and meaning - would not exist in its present form if it were not for the Christian tradition. The corollary of this conviction is that folk belief can no longer be thought of in isolation from Christianity and the dialogue it pursues with religious tradition. This does not imply that there are no non-Christian elements whatsoever in folk belief, or that folk belief is not an alternative, in some senses distinct tradition in relation to religion. What we must ask ourselves, however, is whether it is meaningful to continue to separate them to the extent we have done before, if both contain the same themes, have similar structures, and are incorporated into the same network of associations. In my opinion, this is an indication of the existence of a common store of expressions that can be used to describe supernatural experiences, quite regardless of whether they belong to the sphere of folklore or religion. The composition of this store of expressions, how it is utilised by narrators in their construction of their stories, and what it can tell us about folklore, and culture in general, would deserve further study. Its impact on early modern mentalities and identities, in Finland and elsewhere, would be particularly valuable to know more about.

More generally, the findings presented here reaffirm the importance of relating folklore to other discourses current in society in order to gain a deeper understanding of folk culture. Application of a theory of interdiscursivity significantly facilitates such an understanding, and it can be combined with other theoretical concepts of a similar nature, such as intergenericity, pertaining to the relationship between genres, and between individual narratives and their generic model (cf. Asplund Ingemark 2004, 33-37, 218-279).

To summarise, the role of intertextuality and interdiscursivity in the creation of images of the supernatural in narrative is notable, and so is the part played by Christianity in this process. It has been my ambition to locate some of the constituents of the network of associations in which the troll legends of Vörå were included and - by way of illustration - to suggest ways of reading these and other texts through the lens of Biblical stories. 


\section{SOURCES}

\section{Archival material:}

Svenska litteratursällskapet i Finland (SLS), Folkkultursarkivet.

— SLS 215, 44. Submitted by Jacob Tegengren, Korsnäs 1912-1913.

— SLS 280, 635-636. Submitted by V. E. V. Wessman, Vörå 1917.

— SLS 338, 21-22. Submitted by Elna Källbacka, Vörå 1922.

\section{Printed sources:}

— Hembygden 1912, 20-21. Submitted by J. Kaustinen, Vörå 1912.

\section{REFERENCES}

ANDERSSON, OTTO 1967: Finländsk folklore Åbo: Åttas förlag. ANTTONEN, PERTTI J. 2003: Folklore, History and the "Story of Finland". Tarkka, Lotte (ed.), Dynamics of Tradition. Perspectives on Oral Poetry and Folk. Belief. Studia Fennica Folkloristica 13. Helsinki: Finnish Literature Society. APO, SATU 1989: Class Relations as Reflected in Southwest Finnish Magic Tales. - Siikala, Anna-Leena (ed.), Studies in Oral Narrative. Studia Fennica 33. Helsinki: Suomalaisen Kirjallisuuden Seura.

ASPLUND (INGEMARK), CAMILLA 2001: Intertextuality in Nordic Folklore Research. - Arv, Nordic Yearbook of Folklore 57: 71- 83.

- 2004: The Genre of Trolls. The Case of a Finland-Swedish Folk Belief Tradition. Åbo: Åbo Akademi University Press.

BAKHTIN, MIKHAIL 1986: The Dialogic Imagination. Four Essays by M. M. Bakhtin. Austin: University of Texas Press.

BARTHES, ROLAND 1977: The Death of the Author. - Heath, Stephen (ed.), Image-Music-Text. New York: Hill \& Wang.

BERGMAN, ANNE 1981: Nyländska avdelningens och Svenska litteratursällskapets folkloristiska insamlingsverksamhet 1860-1908. - Fynd och forskning. Till Ragna Ablbäck 17.7.1981. Meddelanden från Folkkultursarkivet 7, Skrifter utgivna av Svenska litteratursällskapet i Finland 496. Helsingfors: Svenska litteratursällskapet i Finland.

BURKE, PETER 1983: Folklig kultur $i$ Europa 1500-1800. Stockholm: Författarförlaget.

DAHLBACKA, INGVAR 1987: Den evangeliska rörelsen i svenska Österbotten 18451910. Åbo: Åbo Akademis förlag.

FAIRCLOUGH, NORMAN 1992: Discourse and Social Change. Cambridge: Polity Press.

FINLANDS 1920: Finlands svenska folkdiktning 1.A.2. - Hackman, Oskar, Skrifter utgivna av Svenska litteratursällskapet i Finland 151. Helsingfors: Svenska litteratursällskapet i Finland. 


\section{Camilla Asplund Ingemark}

FOLEY, JOHN MILES 1991: Immanent Art. From Structure to Meaning in Traditional Oral Epic. Bloomington: Indiana University Press.

FOUCAULT, MICHEL 1980: Power/Knowledge. Selected Interviews and Other Writings 1972-1977. New York: Harvester Wheatsheaf.

- 1999: L'archéologie du savoir. Paris: Gallimard.

— 2002: Histoire de la sexualité 1. Paris: Gallimard.

HALLSTÉN, A. G. J. 1852: Finlands historie och geografi 2. Helsingfors: Öhmanska Bokhandelns förlag.

HARVILAHTI, LAURI 2000: Variation and Memory. - Honko, Lauri (ed.), Thick Corpus, Organic Variation and Textuality in Oral Tradition. Studia Fennica Folkloristica

7. Helsinki: Finnish Literature Society.

- 2001: Substrates and Registers. Trends in Ethnocultural Research. - Wolf-Knuts, Ulrika \& Kaivola-Bregenhöj, Annikki (eds.), Pathways. Approaches to the Study and Teaching of Folklore. NNF Publications 9. Turku: Nordic Network of Folklore.

- 2003: Ethnocultural Substrates in Altay Schamanistic Folklore. - Tarkka, Lotte (ed.), Dynamics of Tradition. Perspectives on Oral Poetry and Folk. Belief. Studia Fennica Folkloristica 13. Helsinki: Finnish Literature Society.

HEMBYGDEN 1910.

HONKO, LAURI 1980: Upptäckten av folkdiktning och nationell identitet i Finland. - Honko, Lauri (ed.), Folklore och nationsbyggande $i$ Norden. NIF Publications 9. Åbo: Nordiska institutet för folkdiktning.

- 1998: Textualising the Siri Epic. FF Communications 264. Helsinki: Academia Scientiarum Fennica.

- 2000: Thick Corpus and Organic Variation. An Introduction. - Honko, Lauri (ed.), Thick Corpus, Organic Variation and Textuality in Oral Tradition. Studia Fennica Folkloristica 7. Helsinki: Finnish Literature Society.

KRISTEVA, JULIA 1978: Sêmeiôtikè. Recherches pour une sémanalyse. Paris: Éditions du Seuil.

MILLS, SARA 2002: Discourse. London: Routledge.

NYLAND 1887: Nyland 2. Helsingfors: Nyländska afdelningen.

NÄSMAN, NILS 1979: Det religiösa livet. - Svenska Österbottens historia 2. Vasa: Svenska Österbottens landskapsförbund.

OLSSON, BIRGER 2001: Från Birgitta till Bibel 2000. Den svenska Bibelns bistoria. Stockholm: Verbum.

PLEIJEL, HILDING 1967: Bibeln. En svensk folkbok? - Våra äldsta folkböcker. Lund: C. W. K. Gleerup Bokförlag.

RIFFATERRE, MICHAEL 1978: Semiotics of Poetry. Bloomington: Indiana University Press.

- 1990: Compulsory Reader Response. The Intertextual Drive. - Worton, Michael \& Still, Judith (eds.), Intertextuality. Theories and Practices. Manchester: Manchester University Press.

SCHYBERGSON, M. G. 1895: Lärobok $i$ allmänna bistorien för lyceernas bottenklasser och fruntimmersskolorna. Stockholm: P. A. Norstedt \& Söners förlag. 
STARK, LAURA 2002: Peasants, Pilgrims and Sacred Promises. Ritual and the Supernatural in Orthodox Karelian Folk Religion. Studia Fennica Folkloristica 11. Helsinki: Finnish Literature Society.

STARK-AROLA, LAURA 1998: Magic, Body and Social Order. The Construction of Gender Through Women's Private Rituals in Traditional Finland. Studia Fennica Folkloristica 5. Helsinki: Finnish Literature Society.

STEINBY, TORSTEN 1985: Forskning och vitterhet 1. Skrifter utgivna av Svenska litteratursällskapet i Finland 523(1). Helsingfors: Svenska litteratursällskapet i Finland.

TARKKA, LOTTE 1993: Intertextuality, Rhetorics and the Interpretation of Oral Poetry. The Case of Archived Orality. - Anttonen, Pertti J. \& Kvideland, Reimund (eds.), Nordic Frontiers. Recent Issues in the Study of Modern Traditional Culture in the Nordic Countries. NIF Publications 27. Turku: Nordic Institute of Folklore. - 1994: Other Worlds. Symbolism, Dialogue and Gender in Karelian Oral Poetry. - Siikala, Anna-Leena \& Vakimo, Sinikka (eds.), Songs beyond the Kalevala. Studia Fennica Folkloristica 2. Helsinki: Suomalaisen Kirjallisuuden Seura.

THURMAN, JANNE 1891: Några hednaminnen i pargasbons folkdiktning. Kalender utgifven af Svenska folkskolans vänner 1891 . Helsingfors: Svenska folkskolans vänner.

WOLF-KNUTS, ULRIKA 1991: Människan och djävulen. En studie kring form, motiv och funktion i folklig tradition. Åbo: Åbo Akademis förlag.

- 1997: Johan Oskar Immanuel Rancken. En pionjär inom folkloristiken. - Norveg 1997(1): 27-45.

- 2000: Djävulen och barnaföderskan. - Hammer, Olav \& Raudvere, Catharina (eds.), Berättelser om ondskan. Stockholm: Wahlström \& Widstrand.

ÅKERBLOM, BROR 1963: Vörå sockens historia 2. Vörå: Vörå kommuns förlag.

Dr. phil Camilla Asplund Ingemark is a postdoctoral researcher affiliated with Åbo Akademi University. She is currently working on a project on folklore in Antiquity, in collaboration with Dr. Dominic Ingemark, Lund University. 